\title{
Origin, expression and possible functions of the two alternatively spliced forms of the mouse Nedd2 mRNA
}

\author{
Sharad Kumar ${ }^{1,3}$, Makoto Kinoshita ${ }^{2}$, Loretta Dorstyn ${ }^{1}$ and \\ Makoto Noda ${ }^{2}$ \\ 1 Hanson Centre for Cancer Research, Institute of Medical and Veterinary \\ Science, P.0. Box 14, Rundle Mall, Adelaide, Australia 5000 \\ 2 Department of Molecular Oncology, Kyoto University School of Medicine, \\ Sakyo-ku, Kyoto, Japan 606 \\ 3 corresponding author: tel: $+61-8-82223738$; fax: $+61-8-82223139$ or \\ +61-8-8232 4092; email: skumar@immuno.imvs.sa.gov.au
}

Received 19.12.96; revised 24.1.97; accepted 27.1.97

Edited by D. Green

\begin{abstract}
The Nedd2 gene, a member of the ICE/ced-3 family, transcribes two mRNA species by differential splicing. One of these encodes a shorter truncated version of the protein termed Nedd2s/ICH-1s. While Nedd2/ICH-1 induces apoptosis, $\mathrm{ICH}-1$ s was proposed to be a negative regulator of cell death. In this communication we have analyzed various aspects of the Nedd2s/ICH-1s. The coding region of mouse Nedd 2 consists of 10 exons and alternative splicing of the 7th exon results in the generation of two transcripts. Although Nedd2s expression conferred partial resistance to serum withdrawal-induced apoptosis in NIH-3T3 cells, it failed to prevent cell death induced by the overexpression of Nedd2 and was unable to suppress apoptosis in two other cell lines (N18 and FDC-P1) under factor deprived conditions. Our results indicate that $\mathrm{Nedd} 2 \mathrm{~s} / \mathrm{ICH}-1 \mathrm{~s}$ is not a general modulator of cell death.
\end{abstract}

Keywords: ICE; CED-3; ICH-1; caspases; apoptosis; protease activation

Abbreviations: ICE, interleukin $1 \beta$-converting enzyme; PCR, polymerase chain reaction; PBS, phosphate buffered saline; DMEM, Dulbecco's modified Eagle's medium

\section{Introduction}

Mammalian homologues of the product of Caenorhabditis elegans cell death gene, ced-3, play essential effector roles in apoptosis (reviewed in Kumar, 1995a; Martin and Green, 1995; Kumar and Lavin, 1996). The first known member of this growing family was interleukin-1 $\beta$ converting enzyme (ICE), a cysteine protease required for the processing of the interleukin-1 $\beta$ precursor (Thornberry et al, 1992; Yuan et al, 1993). Subsequently, several ICE-like proteins have been identified in mammalian cells and caspase has been proposed as a name for the human members of this family
(Alnemri et al, 1996). Of the 11 known members of this family only some such as ICE and CPP32 have been characterised in detail and it is not clear whether all play a role in apoptosis. Mice deficient in ICE develop normally although show some defect in Fas-mediated apoptosis (Li et al, 1995; Kuida et al, 1995). CPP32 deficient mice show a more severe phenotype as characterised by decreased apoptosis in the brain resulting in profound hyperplasia and post-natal lethality (Kuida et al, 1996). Interestingly, CPP32 (-/-) mice only show a defect in neuronal apoptosis during development suggesting that other members of the caspase family may be involved in apoptosis in other tissues and cell lineages.

Caspases are synthesised as precursor molecules and require cleavage into two subunits prior to activation (reviewed in Kumar, 1995a). In vitro, caspases can be cleaved at specific aspartate residues by other members of the family (Fernandes-Alnemri et al, 1996; Xue et al, 1996; Harvey et al, 1996). Some of the caspase family members (eg. CPP32/Yama/apopain, Mch2 and Mch3/ICE-LAP3) have been shown to be activated during apoptosis (Martin et al, 1995; Chinnaiyan et al, 1996; Duan et al, 1996; Orth et al, 1996a,b). Once activated caspases such as CPP32/ Yama/apopain and Mch3/ICE-LAP3 cleave several cellular proteins such as poly (ADP-ribose) polymerase (Nicholson et al, 1995; Fernandes-Alnemri et al, 1995; Tewari et al, 1995), catalytic subunit of the DNA dependent protein kinase (Casciola-Rosen et al, 1996; Song et al, 1996a,b), U1-70 kDa ribonucleoprotein (Casciola-Rosen et al, 1996), heteronuclear ribonucleoproteins $\mathrm{C} 1$ and $\mathrm{C} 2$ (Waterhouse et al, 1996); while Mch2 specifically cleaves lamin A (Orth et al, 1996a; Takahashi et al, 1996).

Mouse Nedd2 (Neural precursor cell-expressed developmentally down-regulated gene 2), a member of the caspase family, was first identified as a developmentally regulated gene in the mouse central nervous system (Kumar et al, 1992). Subsequently, Nedd2 was shown to encode a protein similar to ICE and CED-3 and to induce apoptosis when ectopically expressed in NIH-3T3 and N18 cells (Kumar et al, 1994a). Wang et al. (1994) identified the human counterpart of $\mathrm{Nedd} 2$ and named it $\mathrm{ICH}-1$. We also cloned the human homologue of mouse Nedd2 and according to the recommendations of the genome nomenclature committee, called it NEDD2 (Kumar et al, 1995). The new proposed name for the human ICH-1/ NEDD2 is caspase-2 (Alnemri et al, 1996). Although, currently there is no direct evidence to firmly establish a central role for Nedd2 protease in apoptosis, several studies have provided support that Nedd2 function is required in the cell death pathway. For example, expression of antisense Nedd2 delays apoptosis of a factordependent cell line under factor deprived conditions (Kumar, 1995b). Furthermore, upregulation of Nedd2 mRNA occurs during ischaemia induced neuronal death 
in Mongolian gerbil (Kinoshita et al, 1997), while a downregulation of Nedd2 expression has been demonstrated upon gonadotropin-promoted follicular survival (Flaws et al, 1995). Proteolytic activation of Nedd2 occurs early during apoptosis induced by various stimuli including factor withdrawal, $\gamma$-irradiation and etoposide treatment in several haematopoietic cell lines (N. Harvey, A. Butt and S. Kumar, manuscript in preparation). In vitro, the activation of Nedd2 can be mediated by caspases such as CPP32 and Mch3 (Harvey et al, 1996; Xue et al, 1996) which are known to be activated during apoptosis (Chinnaiyan et al, 1996; Duan et al, 1996; Orth et al, 1996b; Martin et al, 1995).

Further evidence for the involvement of Nedd2 in apoptosis was provided by Wang et al. (1994) who identified two differentially spliced forms of $I \mathrm{CH}-1\left(\mathrm{ICH}-1_{L}\right.$ and $\mathrm{ICH}-1 \mathrm{~s}$ ) with apparently opposing effects on apoptosis. Consistent with the Nedd2 data, $\mathrm{ICH}-1_{\mathrm{L}}$ was found to induce apoptosis in various cell types while an alternatively spliced form encoding a truncated version of the protein $(\mathrm{ICH}-1 \mathrm{~s})$ was shown to protect against serum deprivationinduced death of Rat-1 cells (Wang et al, 1994). From these studies it was unclear whether $\mathrm{ICH}-1$ s protein acts as a general inhibitor of apoptosis in all cell types and whether it exerts its effect by directly competing with $\mathrm{ICH}-1_{\mathrm{L}}$ or acts through another mechanism. In the present study, we have further analyzed the role of the two forms of Nedd2/ICH-1 in apoptosis. We have cloned the mouse and human Nedd2 encoding the short forms of the protein (Nedd2s/ NEDD2s) and demonstrate that both were unable to inhibit apoptosis induced by ectopic expression of Nedd2. We show that while Nedd2s expressing fibroblasts exhibited some protection against serum withdrawal-induced cell death, expression of Nedd2s in a neuroblastoma cell line and a myeloid progenitor cell line failed to show such effects. We have also determined the genomic structure of Nedd2 to show the origin of the two Nedd2 transcripts and analysed the expression of each form in various tissues.

\section{Results \\ cDNA cloning of the human and mouse Nedd2s}

During a screen for the full length cDNA for Nedd2, we isolated several clones from a lung cDNA library which contained an extra $61 \mathrm{bp}$ sequence compared to the majority of cDNA clones. As the insertion of $61 \mathrm{bp}$ resulted in the creation of an inframe termination codon thereby resulting in the truncation of full length Nedd2 protein (Kumar et al, 1994a,b), we call the mRNA Nedd2s. A human cDNA for the shorter protein termed NEDD2s was isolated from a human brain cDNA library (Kumar et al, 1995). The human NEDD2s

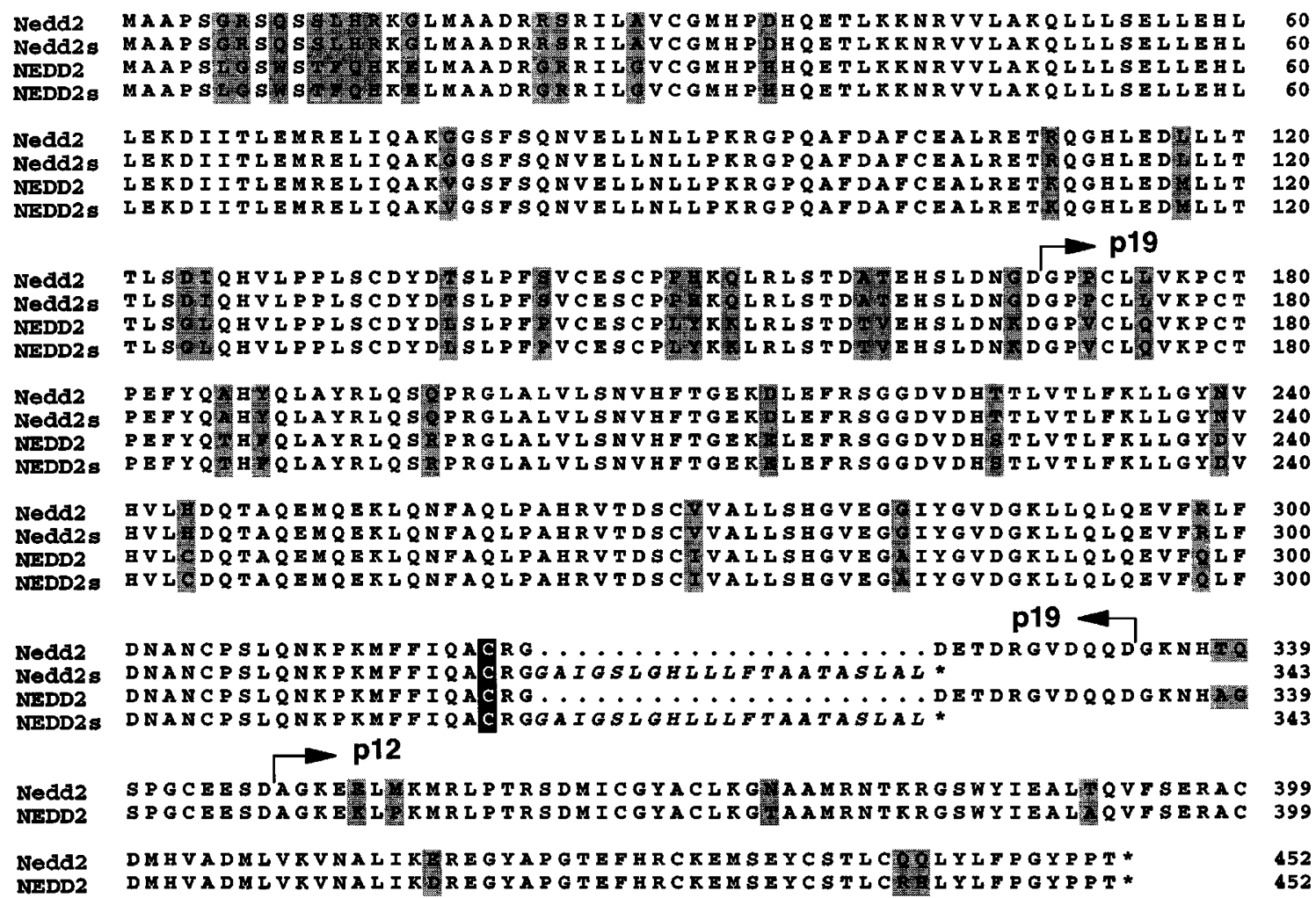

Figure 1 An alignment of the mouse and the human Nedd2 protein sequences. Mouse and human sequences are shown as Nedd2/Nedd2s and NEDD2/NEDD2s, respectively. The numbering in our human sequences (NEDD2 and NEDD2s) differs from those reported for ICH-1 $\mathrm{L}$ and ICH-1s as the sequences reported by Wang et al (1994) appear to lack the amino terminal regions of these proteins. The catalytic cysteine (C) residues are shown in the black boxes and the cleavage sites in Nedd2/NEDD2 sequence which generate p19 and p12 subunits are indicated. The residues not conserved between the mouse and the human proteins are shown in shaded boxes. The sequence unique to the short form of proteins is shown in italics. 
sequence was identical to that reported for $\mathrm{ICH}-1$ s (Wang et al, 1994) except that it contained 31 extra amino acid residues at the amino terminus (Figure 1). To mark this difference, we have used NEDD2s and $\mathrm{ICH}-1$ s respectively for our human cDNA and that of Wang et al. Also due to this difference at the amino terminus, our numbering of amino acid residues is different from that reported for $\mathrm{ICH}-1$. The long and short forms of Nedd2/NEDD2 protein consist of 452 and 343 amino acid residues, respectively (Figure 1 ). The mouse sequences obtained from several lung cDNA clones contained one extra leucine residue (CTC sequence) at position 88 than reported earlier by us (Kumar et al, 1994a). This is consistent with the human NEDD2 sequence and with the recently reported mouse Nedd2 sequence (Allet et al, 1996).

The Nedd2/ICH-1 $1_{\mathrm{L}}$ precursor (proNedd2) is cleaved into p19 and p12 subunits by the action of other ICE-like proteases (Harvey et al, 1996, Xue et al, 1996). The cleavage of pro-Nedd2 occurs after the Asp residues as shown in Figure 1. Thus the two forms of Nedd2 protein differ from each other in two respects: (1) Nedd2s/NEDD2s lacks the region corresponding the $\mathrm{p} 12$ subunit and (2) it lacks 11 residues present at the carboxyl terminus of the p19 subunit, replacing them with 21 unique residues which are identical between the mouse and human proteins (Figure 1). In vitro translation of mRNA derived from Nedd2 and Nedd2s/NEDD2s clones produced protein products of approximately 51 and $38 \mathrm{kDa}$, respectively (data not shown) which is consistent with the predicted sizes from their conceptual translation (Figure 1).

\section{Structure of the coding region of the mouse Nedd2 gene}

Using the Nedd2 cDNA as a probe, genomic DNA fragments of the mouse $\mathrm{Nedd} 2$ were isolated from a phage library. Three independent overlapping clones $(\lambda 6, \lambda 9$ and $\lambda 10)$ with the strongest hybridisation signals were further characterised.
The restriction map and exon-intron structure for the coding region of Nedd2 are shown in Figure 2. Nedd2 and Nedd2s are encoded by a common set of exons clustered along an approximately $15 \mathrm{~kb}$ region of genomic DNA. Nedd2s open reading frame is composed of ten exons and the presence of seventh exon ( $61 \mathrm{bp}$ ) corresponds to the unique sequence to

A

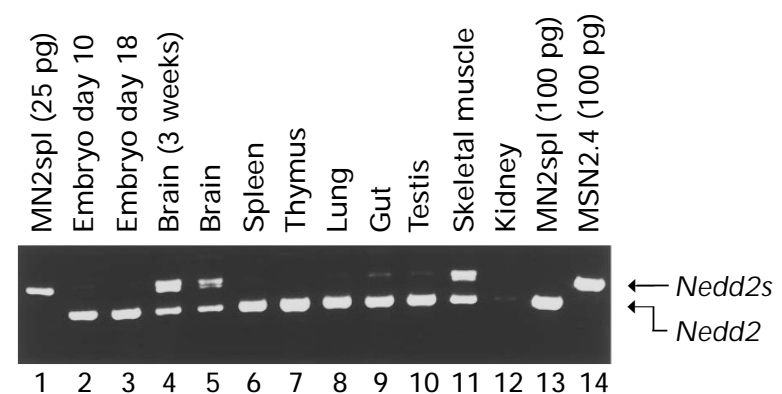

B

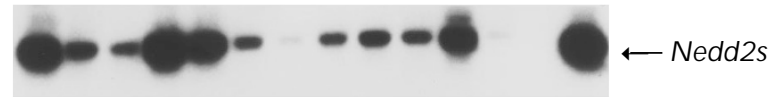

$\begin{array}{llllllllllllll}1 & 2 & 3 & 4 & 5 & 6 & 7 & 8 & 9 & 10 & 11 & 12 & 13 & 14\end{array}$

Figure 3 Relative expression of Nedd2 and Nedd2s mRNA in various mouse tissues. (A) RT - PCR analysis of expression was carried out as described in the methods. The Figure shows a representative example of such an analysis in which PCR was performed for 35 cycles. Note that some of the weaker bands (eg lanes 6 and 7) for Nedd2s are not apparent in the picture due to a loss during photographic reproduction. In (B) the gel shown in $(A)$ was blotted to transfer membrane and hybridised to a 40 base oligonucleotide probe specific for the Nedd2s form. In (A) additional bands visible in brain and skeletal muscle (lanes 4, 5 and 11) just below the Nedd2s band, are probably nonspecific PCR products as these were not detected in all experiments and did not hybridise to Nedd2 probes. Weaker signals in lane 12 (kidney) are probably due to smaller amount of initial RNA sample used for cDNA synthesis. Further experiments confirmed that the levels of Nedd2 mRNA in kidney were similar to those seen in lung and testis (lanes 8 and 10 respectively) and as previously reported (Kumar et al, 1994a). In minus RNA and minus cDNA controls (not shown), no PCR products were visible.

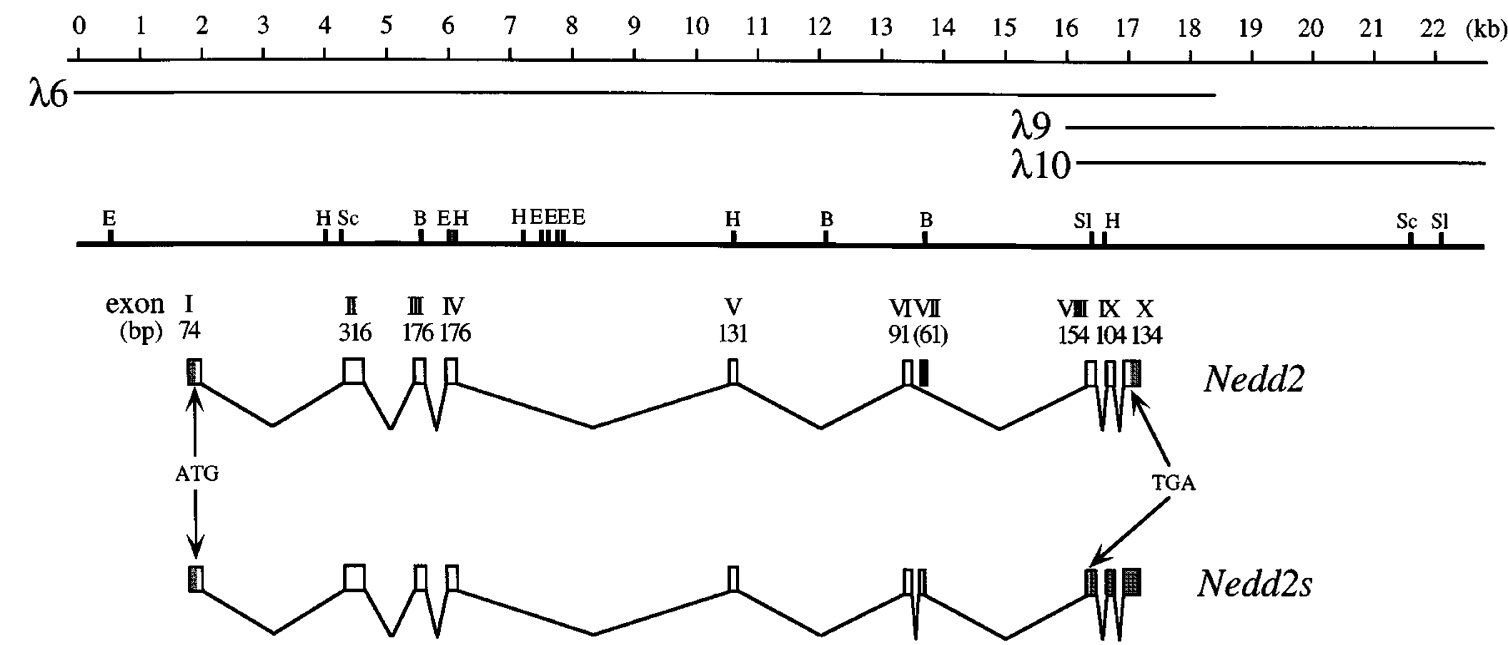

Figure 2 Structure of mouse Nedd2 gene and origin of two alternately spliced mRNA species. Three phage clones, $\lambda 6, \lambda 9$ and $\lambda 10$, are shown with the restriction map. The exon containing the first methionine codon is numbered as exon I. The length of each exon is indicated. Open and shaded segments of the boxes designate translated and untranslated regions of the exons, respectively. A black box designates the seventh exon (exon VII, 61bp), which is alternatively spliced between Nedd2 and Nedd2s. Abbreviations: E; EcoRI, H; HindlII, Sc; Sacl, SI; Sall, ATG; the first methionine codon, TGA; termination codon. 
Table 1 Relative levels of expression of the two alternatively spliced Nedd2 transcripts in various mouse tissues and cell lines as determined by RT-PCR

\begin{tabular}{lc}
\hline Tissue or cell line & $\begin{array}{c}\text { Approximate } \\
\text { Nedd2/Nedd2s ratio }\end{array}$ \\
\hline Total embryo day 10 & 5 \\
Total embryo day18 & 5 \\
Brain (3 week old pups) & 1 \\
Brain & 1 \\
Spleen & 10 \\
Thymus & 15 \\
Lung & 8 \\
Gut & 5 \\
Testis & 5 \\
Skeletal muscle & 1 \\
Kidney & 5 \\
Neural precursor cells & 3 \\
PCC4 (embryonal carcinoma) & 2 \\
N18 (neuroblastoma) & 4 \\
NIH-3T3 (fibroblast) & 5 \\
FDC-P1 (myeloid progenitor) & 5 \\
ES (embryonic stem cells) & 2 \\
\hline
\end{tabular}

These data are representative of several independent experiments.
Table 2 Co-expression of the two forms of Nedd2 fails to prevent apoptosis in $\mathrm{N} 18$ and NIH-3T3 cells

\begin{tabular}{lrr}
\hline & \multicolumn{2}{c}{$\beta$-galactosidase-positive } \\
Expression & \multicolumn{2}{c}{ apoptotic cells } \\
constructs & $1.8 \pm 1.3$ & NIH-3T3 \\
\hline Vector & $96.0 \pm 2.9$ & $1.5 \pm 1.4$ \\
Nedd2 & $1.6 \pm 1.3$ & $90.5 \pm 4.2$ \\
Nedd2-Gly320 & $93.0 \pm 3.5$ & $1.8 \pm 1.2$ \\
Nedd2-Gly320+Nedd2 & $1.5 \pm 1.2$ & $89.7 \pm 4.8$ \\
mN2s & $97.3 \pm 1.2$ & $1.7 \pm 1.8$ \\
mN2s+Nedd2 & $2.7 \pm 1.1$ & $91.2 \pm 4.0$ \\
hN2s & $98.0 \pm 1.2$ & $2.9 \pm 2.2$ \\
hN2s+Nedd2 & & $87.8 \pm 5.7$ \\
\hline
\end{tabular}

Various Nedd2 expression constructs were co-transfected with a $\beta$-galactosidase expression plasmid (pEF- $\beta$ gal) using LIPOFECTAMINE. Cells were fixed 18$24 \mathrm{~h}$ post-transfection, stained with X-gal for $2-6 \mathrm{~h}$, and numbers of blue cells with either normal flat, or small round and apoptotic morphology were scored. The data (mean + SEM) are shown as percentage of morphologically apoptotic cells among all the $\beta$-galactosidase positive blue cells. The data in the Table were derived from observations on at least 600 blue cells for each cell type transfected with various constructs, and were collected from a set of experiments carried out in triplicate. Similar results were obtained in three independent experiments. mN2s and hN2s represent the mouse and human Nedd2s/ NEDD2s, respectively.

\section{Nedd2s fails to prevent cell death induced by Nedd2}

Ectopic expression of the complete coding region of Nedd2/ $/ \mathrm{CH}-1$ induces apoptosis in a number of mammalian cell lines (Kumar et al, 1994a; Wang et al, 1994). We assessed whether this cell death can be inhibited by cotransfecting the two forms in two mouse cell lines, NIH-3T3 (fibroblast) and N18 (neuroblastoma). As shown in Table 2, both mouse and human Nedd2s/NEDD2s were unable to induce apoptosis in both cell types. In addition, both also failed to prevent apoptosis induced by Nedd2. A mutant form of Nedd2 in which the catalytic cysteine residue has been replaced with a glycine residue (Nedd2-Gly320) thereby inactivating the protease activity, is unable to induce apoptosis (Table 2; Kumar et al, 1994a,b). Cotransfection of Nedd2-Gly320 also failed to inhibit Nedd2induced apoptosis. These results suggested that both Nedd2s/NEDD2s and the catalytically inactive mutant do not act as dominant modulators of apoptosis induced by the ectopic expression of Nedd2 protease.

To further analyse the effect of the short form of Nedd2 protein, we generated NIH-3T3 and N18 cells stably transfected with Nedd2s/NEDD2s. When analyzed by Northern blotting, these cells showed detectable production of mRNA generated from the transfected cDNAs (Figure 4). When these cells were transiently transfected with the full length Nedd2, no significant effect was apparent on apoptosis (Table 3). Under similar experimental conditions, NIH-3T3 and N18 cells stably transfected with $\mathrm{Bcl}-2$ showed marked protection of apoptosis induced by the overexpression of Nedd2. Interestingly, N18 cells expressing a part of Nedd2 cDNA in antisense orientation, showed a small but significant delay of apoptosis induced by Nedd2 (Table 3). 
A

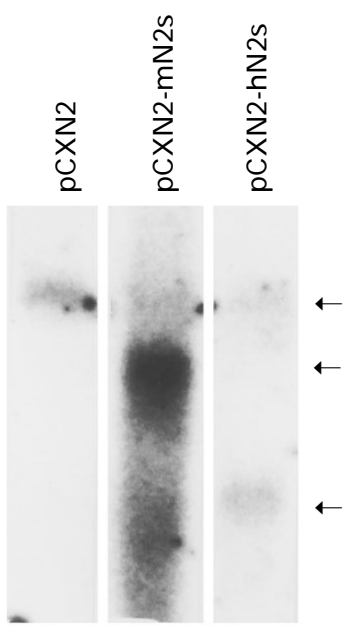

NIH-3T3
B



N18
C

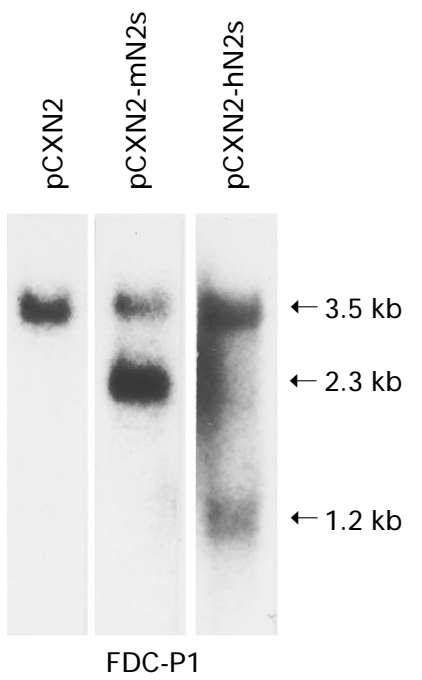

Figure 4 Expression of Nedd2s in the tranfected mouse cell lines. Poly A $^{+}$RNA samples isolated from the pooled G418-selected transfected cells were analysed by Northern blotting using a mouse Nedd2 cDNA probe. Similar results were obtained when a human probe derived from HbN2.1 was used (not shown). The blots were exposed for varying lengths of time ranging from 1-4 days. The $3.5 \mathrm{~kb}$ transcript in all lanes represents the endogenous mouse Nedd2 and serves as an internal control. The $\sim 2.3 \mathrm{~kb}$ and $\sim 1.2 \mathrm{~kb}$ transcripts are derived from transfected mouse and human Nedd2s/NEDD2s respectively. The mouse Nedd2s

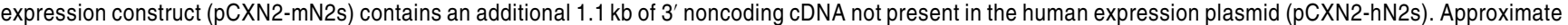
locations of the three transcripts are shown by arrows.

Table 3 Induction of apoptosis by Nedd2 in cells stably expressing Nedd2s

\begin{tabular}{lcc}
\hline Cells & $\begin{array}{c}\beta \text {-galactosidase-positve apoptotic cells (\%) } \\
\text { Vector }\end{array}$ & $\begin{array}{c}\text { Nedd2 } \\
\text { NIH/vector }\end{array}$ \\
NIH/mN2s & $0.9 \pm 0.6$ & $91.1 \pm 4.8$ \\
NIH/hN2s & $0.9 \pm 0.4$ & $85.1 \pm 3.1$ \\
NIH/Bcl-2 & $0.8 \pm 0.7$ & $83.6 \pm 2.5$ \\
N18/vector & $0.8 \pm 0.2$ & $30.2 \pm 6.2$ \\
N18/mN2s & $1.3 \pm 0.8$ & $95.0 \pm 3.3$ \\
N18/hN2s & $2.3 \pm 1.3$ & $90.4 \pm 5.9$ \\
N18/Bcl-2 & $1.7 \pm 1.5$ & $89.7 \pm 1.9$ \\
N18/Nedd2AS & $2.4 \pm 1.1$ & $31.2 \pm 5.9$ \\
\hline
\end{tabular}

Pooled NIH-3T3 or N18 cells stably transfected with the indicated expression constructs were transiently transfected using LIPOFECTAMINE with either pCXN2 (Vector) or pCXN2-N2 (Nedd2), and pEF- $\beta$ gal. Cells were fixed 18-24 h post-transfection, stained with X-gal for $2-6 \mathrm{~h}$ and scored as in Table 2 . Although the data (mean + SEM) shown in the table were derived from a single experiment done in triplicate, similar results were obtained in three separate experiments. mN2s and hN2s represent the mouse and human Nedd2s/ NEDD2s, respectively. Nedd2AS contains part of the mouse Nedd2 cDNA in antisense orientation.

\section{Inhibition of apoptosis in Nedd2s expressing cells under serum- or factor-deprived condition}

Since $\mathrm{ICH}-1$ s has been shown to inhibit apoptosis in Rat-1 cells under serum-free conditions, in further experiments we analyzed whether NIH-3T3 and N18 cells expressing Nedd2s show any suppression or delay of cell death under factor-deprived conditions. As shown in Figure $5 \mathrm{~A}$, more than $90 \%$ of the $\mathrm{NIH}-3 \mathrm{~T} 3$ transfected with pCXN2 vector alone died within 7 days, while more than $50 \%$ of the cells expressing $\mathrm{Bcl}-2$ remained viable during this period. $\mathrm{NIH}-$
3T3 cells transfected with either the mouse or the human Nedd2s/NEDD2s showed small but significant inhibition of death induced by serum deprivation and at 7 days postserum withdrawal, $>20 \%$ of the cells were still viable (Figure 5A). While N18 cells transfected with Bcl-2 showed significant resistance to death induced by serum-depletion, in these cells, both human and mouse Nedd2s/NEDD2s were unable to inhibit or delay apoptosis (Figure 5B). The levels of mRNA for Nedd2s/NEDD2s were similar in two transfected cell lines (Figure 4). Therefore it appears that the differences observed in these experiments are due to cell type. This was further evident when a factor dependent myeloid progenitor cell line FDC-P1 was used in similar experiments. In the absence of cytokine (GM-CSF or IL-3), FDC-P1 cells die rapidly by apoptosis. Although FDC-P1 cells transfected with $\mathrm{Bcl}-2$ were significantly resistant to apoptosis induced by GM-CSF withdrawal, no significant inhibitory effect was seen with either human or mouse Nedd2s/NEDD2s expression (Figure 5C).

\section{Co-expression of the p19 and p12 subunits of Nedd2 fails to induce cell death}

The main difference between the $\mathrm{p} 19$ subunit of $\mathrm{Nedd} / \mathrm{ICH}$ $1_{\mathrm{L}}$ and $\mathrm{Nedd} 2 \mathrm{~s} / \mathrm{ICH}-1 \mathrm{~s}$ is that in $\mathrm{Nedd} 2 \mathrm{~s} / \mathrm{ICH}-1 \mathrm{~s}$ the 11 amino acid residues at the carboxyl terminus are replaced by 21 amino acid residues derived from the alternatively spliced exon 7. Importantly, Nedd2s/ICH-1s protein retains the crucial residues of p19 subunit which correspond to the ones implicated in catalysis and substrate binding in the p20 subunit of ICE (Walker et al, 1994; Wilson et al, 1994). Thus it was of interest to check whether the co-expression of Nedd2s with the p12 subunit would generate an active enzyme and 
induce apoptosis. We generated expression constructs carrying only the regions of cDNA corresponding to the $p 19$, p12 and p20 (Nedd2s) subunits. Surprisingly, co-transfection of p19 and p12 subunits of Nedd2 into NIH-3T3 cells failed to induce apoptosis (Figure 6). Indeed, cotransfection of the p20 Nedd2s with p12 was also unable to induce apoptosis in NIH3T3 cells (Figure 6). In further experiments, we cotransfected p12 expression construct and constructs carrying either the prodomain+p19 (pCXN2-N2N) or prodomain+p20 (pCXN2$\mathrm{N} 2 \mathrm{~s}$ ) into NIH-3T3 cells. Again, these constructs failed to induce apoptosis (Figure 6). Since full length cDNA encoding the p51 pro-Nedd2 is capable of inducing apoptosis owing to its protease activity, these experiments suggest that an intact precursor is required for the correct processing and folding of the protease.

\section{Discussion}

Among the members of the caspase family, Nedd2/ICH-1 shares limited similarity with the ICE-subfamily and the CPP32-subfamily (reviewed in Kumar and Lavin, 1996). Nedd2 protease has not been extensively characterised and its substrate specificity and downstream targets remain unknown. Some of our recent work has shown that Nedd2 fails to cleave proteins that are cleaved by CPP32 and Mch3 (Waterhouse et al, 1996; our unpublished data), despite the fact it shows some activity on DEVD-AFC, a fluorogenic tetrapeptide substrate of CPP32 (Harvey et al, 1996; Xue et al, 1996). In addition, Nedd2 is only partially inhibited by the baculovirus p35 and not inhibited by the cowpox virus protein CrmA (Wang et al, 1994a,b; Xue and Horvitz, 1995; L. Dorstyn
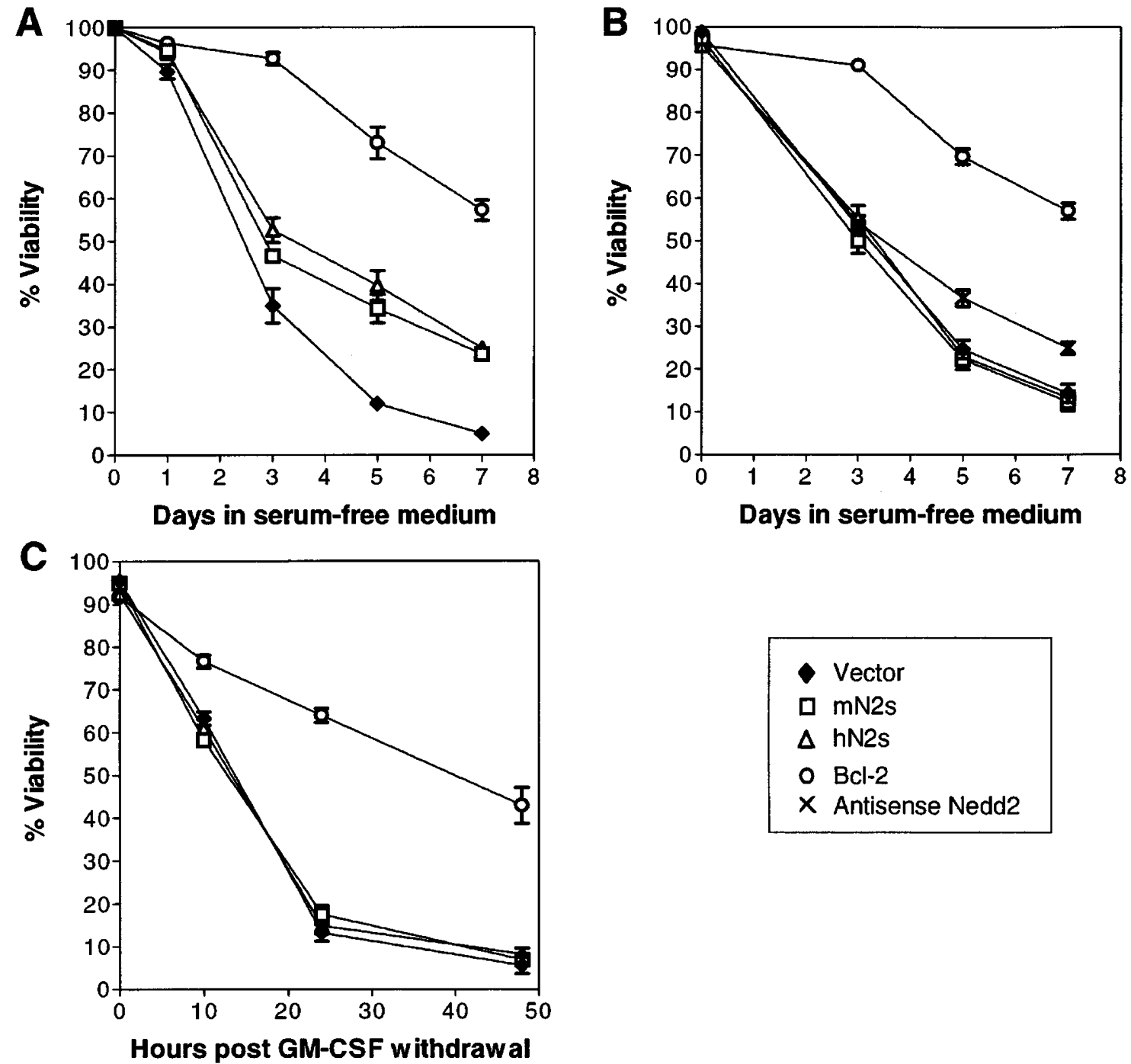

Figure 5 Effect of serum/factor withdrawal on apoptosis in cells expressing the smaller form of Nedd2. (A) NIH-3T3; (B) N18 and (C) FDC-P1. Pooled populations of transfectants were plated in complete medium. Following day, cells were washed and medium replaced with serum-free (NIH-3T3 and N18) or GM-CSF-free medium (FDC-P1). At indicated times, cells were analyzed for viable population by trypan blue exclusion. Data shown were derived from a single experiment done in triplicate. Similar results were obtained in at least two experiments. 


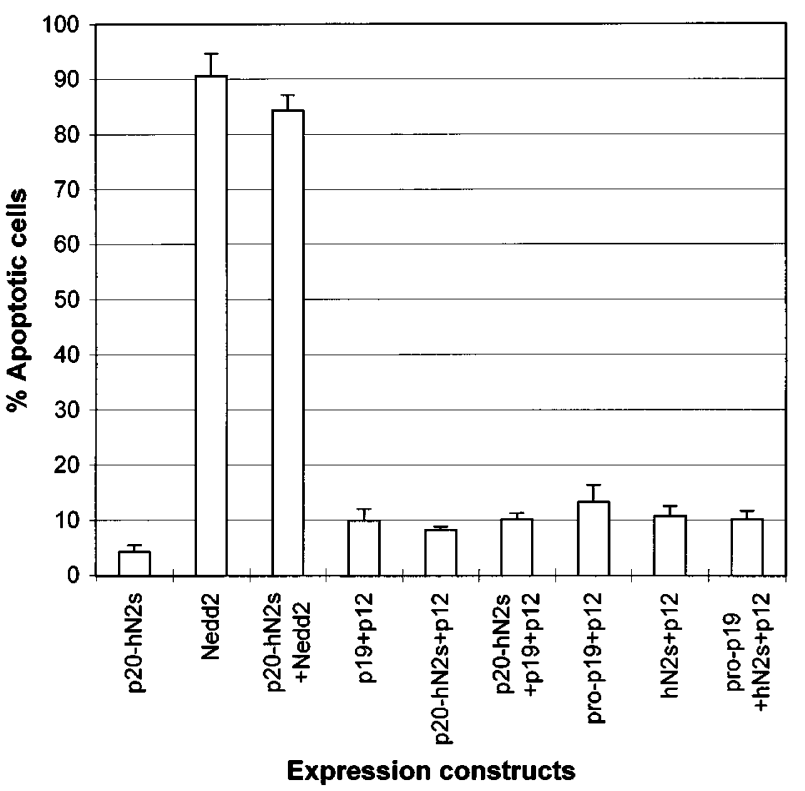

Figure 6 Co-transfection of the cDNA encoding two subunits of Nedd2 fails to induce apoptosis. Various expression constructs were co-transfected with pEF- $\beta$ gal into NIH-3T3 cells by lipofection using DOSPER. At $18 \mathrm{~h}$ posttransfection cells were fixed, stained with X-gal and blue cells observed for apoptosis. Bars represent apoptotic cells as $\%$ of total $\beta$-galactosidase $+v e$ cells \pm SEM. At least 600 blue cells were scored for each dish. The data shown were derived from an experiment done in triplicate. Similar results were obtained in three independent experiments. pCXN2-p20s (p20-hN2s) lacks the NEDD2s prodomain. pCXN2-p19 (p19) and pCXN2-p12 (p12) contain only the regions of cDNA corresponding to the two subunits of Nedd2. pCXN2-N2N (pro-p19) contains the region of cDNA encoding the amino terminal 328 amino acid residues.

and S. Kumar, unpublished data). Although, as mentioned earlier, there are several lines of evidence to suggest a role for Nedd2 in apoptosis, a direct demonstration for this is lacking. Perhaps the most convincing evidence was the demonstration by Wang et al. (1994) that the short form of $\mathrm{ICH}-1$ generated by alternative splicing can inhibit serum deprivation induced apoptosis in Rat-1 fibroblasts.

In most tissues, the expression of Nedd2 is low (Kumar et al, 1994). Except for brain and skeletal muscle, where the levels of both transcripts are low but both are expressed in equal ratio, Nedd2s is a minor transcript. One can argue that lower Nedd2: Nedd2s ratio in tissues with low cell turnover such as brain and skeletal mucle, and higher ratio in tissues where substantial cell death occurs such as thymus and spleen, might suggest an apoptosis inhibitory function for the shorter protein. Whether this is relevant in a physiological context remains to be determined. Co-transfection of the two forms, which is likely to generate equal levels of mRNA for the two proteins, kills cells as efficiently as the long form of Nedd2. This suggests that the level of the long form of Nedd2 and not that of Nedd2s, might dictate the fate of the cell. This is further supported by our observation that in Mongolian gerbils, both forms of Nedd2 are upregulated to similar extent upon transient forebrain ischaemia (Kinoshita et al, 1997).
Our results with $\mathrm{NIH}-3 \mathrm{~T} 3$ cells expressing either the mouse or the human Nedd2s are consistent with the Rat1 results, however, no such inhibition of cell death was seen in two other cell lines. As suggested by Wang et al. (1994), in NIH-3T3 and Rat-1 cells the partial inhibition of apoptosis induced by serum withdrawal may be due either to (1) the competition between the p19/p20-Nedd2s for the p12 subunit, or (2) interaction of Nedd2s with some other apoptosis regulator. If the first possibility was true, the levels of expression of the two form would determine the extent of apoptosis. This however does not appear to be the case as in transient co-transfection experiments where two forms are likely to be expressed in roughly equal levels, no inhibition of Nedd2 induced apoptosis was evident. Moreover, in N18 and FDC-P1 cells, where the ratio of two forms is comparable to that in NIH-3T3 cells, no protection from serum- or factor- withdrawal induced apoptosis is seen. In isolated Nedd2s/NEDD2s transfected clones expressing varying levels of the transcript, results similar to those shown in Figure 5 were obtained (data not shown). These observations suggest that Nedd2s/ICH-1s is unlikely to act by competing with Nedd2/ICH-1. In NIH-3T3 and Rat-1 cells, the effect of Nedd2s/ICH-1 may be mediated by interaction with components other than $\mathrm{Nedd} 2 / \mathrm{ICH}-1$. Cross species interactions between subunits derived from different ICE-like proteases has been demonstrated (eg. $\mathrm{Gu}$ et al, 1995; Fernandes-Alnemri et al, 1995). Whether Nedd2s also functions to inhibit apoptosis in Rat-1 and $\mathrm{NIH}-3 \mathrm{~T} 3$ cells by interacting with the smaller subunits of other caspases, remains to be determined. The differential effect of Nedd2s seen in three cell lines used in our study may be due to the different levels of expression of various caspases or other molecules which interact with Nedd2s in these cells.

Some members of the caspase family such as Nedd2, ICE, ICE rel $^{-I I}$, ICE rel- $^{-I I I}$, Mch4 and Mch5/FLICE/MACH contain relatively long prodomains, while others including CPP32, Mch2 and Mch3, the prodomain consists of a very short stretch of amino acid residues (see Kumar and Lavin, 1996 for some examples). Based on recent findings it appears that the function of the long prodomains in some caspases is to act as an adaptor to link the proteases to a death signalling complex. For example, the prodomain of FLICE/MACH binds to FADD, a protein which is recruited to the death complex upon activation of Fas/APO-1 receptor (Boldin et al, 1996; Muzio et al, 1996). Another function of the prodomain of caspases is evident from a recent study which shows that the prodomain of ICE is required for dimerisation prior to the processing of pro-ICE (Van Criekinge et al, 1996). The experiments reported in this paper demonstrate that cotransfection of the p12 and p19 subunits fails to induce apoptosis. We have also noticed that in vitro mixing and refolding of the $\mathrm{p} 19$ and 12 subunits of Nedd2 expressed in $E$. coli fails to generate catalytically active Nedd2 enzyme ( $N$. Harvey et al, unpublished observations). A recent study by Allet et al (1996) also supports our conclusions. These authors have shown that while microinjection of the full length Nedd2 cDNA expression construct into sympathetic neurons results in apoptosis, expression constructs lacking the 
prodomain or containing only the regions corresponding to the two subunits ( $p 19$ and $p 12$ ) fail to trigger cell death. These data suggest that the intact prodomain of Nedd2 is essential for function and might be required for proper dimerisation of the precursor prior to processing, or interaction with other proteins. Nedd2 and Nedd2s share identical prodomains and p19 differs from Nedd2s by only a few amino acid residues at the carboxyl terminus. Thus, Nedd2 and Nedd2s may heteromerise through their prodomains. Whether this occurs in vivo and has an effect on the outcome of the apoptotic response of a cell, awaits further studies.

\section{Materials and Methods \\ cDNA cloning of the human and mouse Nedd2s/ NEDD2s}

Using an EcoRl fragment of mouse Nedd2 cDNA as a probe (Kumar et al, 1994a,b), we screened approximately $5 \times 10^{5}$ clones from a human foetal brain cDNA library (Stratagene) by standard protocols (Sambrook et al, 1989) and isolated two NEDD2/ICH-1 cDNA clones (HbN2.1 and HbN2.3) (Kumar et al, 1995). These clones contained approximately $1.1 \mathrm{~kb}$ and $0.8 \mathrm{~kb} \mathrm{cDNA}$ inserts, respectively, covering a part of the $5^{\prime}$ region of the human NEDD2 mRNA. HbN2.1 clone contained the entire coding region of the shorter form of NEDD2/ICH-1 protein (NEDD2s//CH-1s) (Kumar et al, 1995). Three partial cDNA clones containing the $61 \mathrm{bp}$ sequence from the alternatively spliced exon were isolated from a mouse lung cDNA library (Stratagene). To create a complete coding cDNA for the mouse Nedd2s, the $0.29 \mathrm{~kb}$ HindlII/Sall fragment of the clone MSN2.4, encoding the long form of Nedd2 (Kumar et al, 1994a) was replaced by a $0.35 \mathrm{~kb}$ HindllI/Sall fragment from clone MLN2.3 containing the $61 \mathrm{bp}$ exon. This plasmid was named MN2spl.

\section{Isolation and mapping of the mouse Nedd2 genomic DNA clones}

A mouse genomic DNA library in $\lambda$ FIX II (Stratagene) was screened with $\left[\alpha^{32} \mathrm{P}\right]$-labelled probe generated by a random priming method from a cDNA fragment isolated from clone MN2.4, which contains the entire open reading frame of Nedd2 (Kumar et al, 1994a). By screening $4 \times 10^{5}$ plaques we isolated 11 positive clones after three cycles of screening and harvested phage DNA from three independent clones $(\lambda 6, \lambda 9$ and $\lambda 10)$ with the strongest hybridisation signals. Restriction mapping (Accl, BamHI, EcoRI, EcoRV, HindllI, Mlul, Notl, Pstl, Sall, Smal, Spel, Sstl, Xbal and Xhol) combined with Southern hybridisation using several oligonucleotide probes revealed that the three clones overlapped and $\lambda 6(18.5 \mathrm{~kb})$ contained all the exons for the coding regions of Nedd2 and Nedd2s mRNAs (Figure 2). Several of the restriction fragments of these clones were subcloned in pBluescript SK(-) (Stratagene) and sequences around the exonintron junctions determined by using a series of primers synthesised based on the cDNA sequence.

\section{RNA isolation and expression analysis}

Total RNA was prepared from cultured cells and mouse tissues using RNAzol $B$ according to the instructions provided by the manufacturers (Tel-Test, Inc.). Poly $\mathrm{A}^{+}$RNA was isolated by oligo dT batch absorption (Sambrook et al, 1989). Samples were electrophoresed on $1.2 \%$ agarose/2.2 $\mathrm{M}$ formaldehyde gels, transferred to Biodyne $\mathrm{A}$ membrane (Pall) and hybridised to probes labelled with $\left[\alpha^{32} \mathrm{P}\right]-\mathrm{dCTP}$ by random priming. Mouse Nedd2 probe was a $2.2 \mathrm{~kb}$ BamHI/Xhol fragment of the clone MSN2.4 representing the entire coding region of the cDNA (Kumar et al, 1994a). Human NEDD2/ICH-1 probe was derived as a $0.8 \mathrm{~kb}$ EcoRl fragment of the clone HbN2.3 (Kumar et al, 1995). For PCR detection of Nedd2 and Nedd2s transcripts, two oligonucleotide primers 5'-CAGAATTTTGCACAGTTACCTGCAC and 5 '-CAAGCATAGCCACATATCATGTCTG, representing the sequences upstream and downstream of the $61 \mathrm{bp}$ alternatively spliced sequence in Nedd2s were used. Using these primers, Nedd2 and Nedd2s transcripts generate PCR products of 343 and $404 \mathrm{bp}$ respectively. cDNA was synthesized from $1 \mu \mathrm{g}$ of poly $\mathrm{A}^{+} \mathrm{RNA}$ using Superscript (Life-Technologies). Ten percent of the cDNA or 25$100 \mathrm{pg}$ of plasmid DNA containing Nedd2/Nedd2s cDNA were amplified by 35 cycles of PCR with each cycle consisting of $1 \mathrm{~min}$ incubation each at $92^{\circ}, 65^{\circ}$ and $72^{\circ} \mathrm{C}$. PCR products were analyzed on $1.5 \%$ agarose gels and when necessary tranferred to Biodyne A (Pall) and hybridised either to a ${ }^{32} \mathrm{P}$ - labelled oligonucleotide probe specific for Nedd2s form (a 40 base antisense oligonucleotide from exon 7 sequence in Figure 2), or a cDNA probe as described above. Relative signal intensities for the two transcripts were estimated by densitometry as described previously (Kinoshita et al, 1997).

\section{Construction of expression vectors}

Construction of the Nedd2 expression plasmids pCXN2-N2, pCXN2N2 Gly-320, pCXN2-N2N (containing the region of cDNA encoding Nedd2 prodomain plus the p19 subunit) and pCXN2-N2AS have been described previously (Kumar et al, 1994a; Kumar, 1995b). pCXN2-N2 contains the entire coding region of Nedd2 cDNA in pCXN2 mammalian expression vector (Niwa et al, 1991). An antisense expression vector (pCXN2-N2AS) was constructed by cloning the blunt ended $1.0 \mathrm{~kb}$ Sall fragment in antisense orientation with respect to $\beta$-actin promoter in pCXN2 vector. pCXN2-N2 Gly-320 contains entire ORF of Nedd2 but carries a cysteine to glycine substitution at position 320 (Figure 1). pCXN2-mN2s was created by blunt end ligation of the T4 polymerase treated $2.2 \mathrm{~kb} \mathrm{Apal} / \mathrm{Xbal}$ fragment from pMN2spl into the EcoRI digested/T4 polymerase treated pCXN2

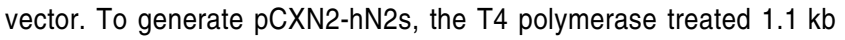
fragment of $\mathrm{HbN} 2.1$ was inserted into pCXN2 as above. To construct the p19, p12 and p20 (hN2s minus the prodomain) expression vectors (pCXN2-p19, pCXN2-p12 and pCXN2-p20s, respectively), regions of the Nedd2 cDNA corresponding to these subunits were amplified by $P C R$ and cloned blunt ended into pCXN2. Following primers were used for PCR: 5'-GCCGCCATGGGTCCTCCCTGTCTTCTG and 5'-GAGAGATCAATCTTGCTGGTCGACACC (p19); 5'-GCCGCCATGGCTGGCAAAGAGGAGTTG and 5'-GAGAGATCACGTGGGTGGGTAGCC (p12); 5'-GCCGCCATGGGTCCTGTCTGCCTTCAG and 5'-GAGAGATTACAGAGCAAGA $\overline{G A G G C}$ (p20s).

In all cases, an optimised Kozak sequence with ATG (underlined) was inserted in frame at the start of protein coding sequence by PCR.

\section{Cell culture and transfection}

Cells were maintained as described previously (Kumar et al, 1994b; Kumar, 1995). In transient transfection studies, NIH-3T3 and N18 cells were plated at a density of $2 \times 10^{5}$ cells $/ 35 \mathrm{~mm}$ dish. The following day, $2.5 \mu \mathrm{g}$ of pCXN2 plasmid constructs and, where indicated, $0.5 \mu \mathrm{g}$ of a $\beta$-galactosidase expression vector ( $\mathrm{pEF}-\beta$ gal) were co-transfected using $10 \mu \mathrm{l}$ of Lipofectamine (Life Technologies) as described (Kumar et al, 1994a). In some experiments (eg. Figure 6), DOSPER reagent (Boeringer-Mannheim) was used for transfection. For $\beta$-galactosidase expression analysis, at 18-24 h post-transfection cells were rinsed with PBS, fixed with $2 \%$ formaldehyde, $0.2 \%$ glutaraldehyde in PBS for 
$5 \mathrm{~min}$, washed twice with PBS, and stained for $2-6 \mathrm{~h}$ with $0.1 \% \mathrm{X}$-gal, $5 \mathrm{mM}$ potassium ferricyanide, $5 \mathrm{mM}$ potassium ferrocyanide, $2 \mathrm{mM}$ $\mathrm{MgCl}_{2}$ in PBS. After rinsing in PBS, $\beta$-galactosidase positive cells were microscopically observed for apoptosis. All transient trasfection experiments were carried out in triplicate and were performed at least three times. In these assays, some variations were obvious between different sets of experiments employing different batches of cells, but overall results were similar. NIH-3T3 and N18 cells expressing $\mathrm{Bcl}-2$ have been described elsewhere (Kumar et al, 1994a). Murine myeloid progenitor cell line FDC-P1 was transfected and selected using Lipofectamine as described previously (Kumar, 1995b). Briefly, $4 \mu \mathrm{g}$ of plasmid DNA in $0.5 \mathrm{ml}$ OPTIMEM (Life Technologies) was mixed with $10 \mu \mathrm{l}$ of Lipofectamine in $0.5 \mathrm{ml}$ OPTIMEM and incubated at room temperature for $30 \mathrm{~min}$. FDC-P1 cells $\left(10^{6} /\right.$ transfection) were washed once in OPTIMEM, resuspended in DNA/Lipofectamine mix, supplemented with 40 units/ml GM-CSF, and plated into a 6-well dish. After $6 \mathrm{~h}$ incubation at $37^{\circ} \mathrm{C}$, each well was fed with $3 \mathrm{ml}$ of OPTIMEM containing $20 \% \mathrm{FCS}$ and 40 units $/ \mathrm{ml}$ GM-CSF. The following day, cells were pelleted, washed and plated in DMEM supplemented with 10\% FCS, 40 units $/ \mathrm{ml}$ GM-CSF and appropriate drug for selection. Transfected cells were selected for antibiotic resistance for 2-4 weeks prior to cloning.

\section{Cell death assays}

For serum withdrawal experiments $\mathrm{NIH}-3 \mathrm{~T} 3$ or $\mathrm{N} 18$ cells were plated at a density of $2 \times 10^{5}$ cells/well in a 6 -well tray. Semiconfluent cell monolayers were washed three times in PBS and refed with DMEM without foetal calf serum. At $24 \mathrm{~h}$ intervals, cells were harvested and assessed for viability. Detached cells in the culture supernatants were collected by centrifugation. Adherent cells were washed with PBS and trypsinised. Fractions from supernatant, washes and trypsinised cells were pooled and recovered by centrifugation. Pellets were resuspended in $0.5-1.0 \mathrm{ml}$ PBS and viability and apoptosis determined by trypan blue exclusion and nuclear staining respectively. In experiments employing FDC-P1 cells, cell were washed in DMEM supplemented with FCS three times and resuspended at $2 \times 10^{6} \mathrm{cells} / \mathrm{ml}$ in the same medium. One hundred $\mu \mathrm{l}$ aliquots were incubated in 96-well tray for the desired length of time. In control experiments, cells were washed in a similar way and resuspended in medium containing 40 units $/ \mathrm{ml}$ of GM-CSF to account for the cell death which may occur during washing procedures. Equal volumes of cell suspension were mixed with $0.8 \%$ trypan blue and dye positive and negative cells were counted using a haemocytometer. In these experiments, at time zero (soon after the washing steps), typically more than $90 \%$ cells were viable as determined by trypan blue dye exclusion. In all cell death experiments, cells were examined and scored for apoptosis-associated morphological changes.

\section{Acknowledgements}

We thank Gayathri Parasivam for excellent technical assistance, Jun-ichi Miyazaki for providing the pCXN2 vector and David Vaux for the Bcl-2 expression construct. This work was supported by a project grant from the National Health and Medical Research Council of Australia (NHMRC no. 960532) and a Wellcome Trust Senior Research Fellowship in Medical Science (grant no. 043629/Z/95) to S.K.

\section{References}

Allet B, Hochmann A, Martinou I, Berger A, Missotten M, Antonsson B, Sadoul R Martinou J-C and Bernasconi L (1996) Dissecting processing and apoptotic activity of a cysteine protease by mutant analysis. J. Cell Biol. 135: 480-486
Alnemri ES, Livingston DJ, Nicholson DW, Salvesen G, Thornberry NA, Wong WW and Yuan J (1996) Human ICE/CED-3 protease nomenclature. Cell 87: 171

Boldin MP, Goncharov TM, Goltsev YV and Wallach D (1996) Involvement of MACH, a novel MORT1/FADD-interacting protease, in Fas/APO-1 and TNF receptorinduced cell death. Cell 85: 803-815

Casciola-Rosen L, Nicholson DW, Chong KR, Rowan KR, Thornberry NA, Miller DK and Rosen A (1996) Apopain/CPP32 cleaves proteins that are essential for cellular repair: a fundamental principle of apoptotic death. J. Exp. Med. 183: 1957-1964

Chinnaiyan AM, Orth K, O'Rourke K, Duan H, Poirier GG and Dixit VM (1996) Molecular ordering of the cell death pathway. J. Biol. Chem. 271: 4573-4576

Duan H, Chinnaiyan AM, Hudson PL, Wing JP, He W-W and Dixit VM (1996) ICELAP3, a novel mammalian homolog of the Caenorhabditis elegans cell death protein CED-3 is activated during Fas- and tumor necrosis factor-induced apoptosis. J. Biol. Chem. 271: 35031-35035

Fernandes-Alnemri T, Armstrong R, Krebs J, Srinivasula SM, Wang L, Bullrich F, Fritz LC, Trapani JA, Tomaselli KJ, Litwack G and AlnemriES (1996) In vitroactivation of CPP32 and Mch3 by Mch4, a novel human apoptotic cysteine protease containing two FADD-like domains. Proc. Natl. Acad. Sci. USA 93: 7464-7469

Fernandes-Alnemri T,Takahashi A, Armstrong R, Krebs J, Fritz L, Tomaselli KJ, Wang L, Yu Z, Croce CM, Salveson G, Earnshaw WC, Litwack G and Alnemri ES (1995) Mch3, a novel human apoptotic cysteine protease highly related to CPP32. Cancer Res. 55: 6045-6052

Flaws JA, Kuju K, Trbovich AM, DeSanti A, Tilly KI, Hirshfield AN and Tilly JL (1995) Interleukin-1beta-converting enzyme-related proteases (IRPs) and mammalian cell death: Dissociation of IRP-induced oligonucleosomal endonuclease activity from morphological apoptosis in granulosa cells of the ovarian follicle. Endocrinology 136: 5042-5053

Gu Y, Wu J, Faucheu C, Lalanne J-L, Diu A, Livingston D and Su MS-S (1995) Interleukin-1 $\beta$ converting enzyme requires oligomerization for activity of processed forms in vivo. EMBO J. 14: 1923-1931

Harvey NL, Trapani JA, Fernandes-Alnemri T, Litwack G, Alnemri ES and Kumar S (1996) Processing of the Nedd2 precursor by ICE-like proteases and granzyme B. Genes Cells 1:673-685

Kinoshita M, Tomimoto H, Kinoshita A, Kumar S and Noda M (1997) Upregulation of the Nedd2 gene encoding an ICE/Ced-3-like cysteine protease in the gerbil brain after transient global ischemia. J. Cereb. Blood Flow Metab. In press

Kuida K, Lippke JA, Ku G, Harding MW, Livingston DJ, Su MS-S and FlavellRA (1995) Altered cytokine export and apoptosis in mice deficient in interleukin-1beta converting enzyme. Science 267: 2000-2003

Kuida K, Zheng TS, Na S, Kuan C, Yang D, Karasuyama H, Rakic P and Flavell RA (1996) Decreased apoptosis in the brain and premature lethality in CPP32deficient mice. Nature 384: 368-372

Kumar S (1995a) ICE-like proteases in apoptosis. Trends Biochem. Sci. 20: 198202

Kumar S (1995b) Inhibition of apoptosis by the expression of antisense Nedd2. FEBS Letters 368: 69-72

Kumar S, Kinoshita M, Noda M, Copeland NG and Jenkins NA (1994a) Induction of apoptosis by the mouse Nedd2 gene, which encodes a protein similar to the product of the Caenorhabditis elegans cell death gene ced-3and the mammalian IL-1 $\beta$-converting enzyme. Genes Develop. 8: 1613-1626

Kumar S and Lavin MF (1996) The ICE family of cysteine proteases as effectors of cell death. Cell Death Differ. 3: 255-267

Kumar S, Tomooka Y and Noda M (1992) Identification of a set of genes with developmentally down-regulated expression in the mouse brain. Biochem. Biophys. Res. Commun. 185: 1155-1161

Kumar S, White DL, Takai S, Turczynowicz S, Juttner CA and Hughes TP (1995) Apoptosis regulatory gene NEDD2 maps to human chromosome segment 7q3435 , a region frequently affected in haematological neoplasms. Human Genet. 95: $641-644$

Kumar S, Yoshida Y, Matsuzaki T and Noda M (1994b) Molecular cloning and biological activity of a novel developmentally regulated gene encoding a protein with transducin $\beta$-like structure. J. Biol. Chem. 269: 11318-11326 
Li P, Allen H, Banerjee S, Franklin S, Herzog L, Johnston C, McDowell J, Paskind M, Rodman L, Salfeld J, Towne E, Tracey D, Wardwell S, Wei F-Y Wong W, Kamen R and Seshadri T (1995) Mice deficient in IL-1 $\beta$ converting enzyme are defective in production of mature $\mathrm{IL}-1 \beta$ and resistant to endotoxin shock. Cell 80: 401-411

Martin SJ and Green DR (1995) Protease activation during apoptosis: Death by a thousand cuts. Cell 82: $349-352$

Martin SJ, Newmeyer DD, Mathias S, Farschon DM, Wang H-G, Reed JC, Kolesnick RN and Green DR (1995) Cell-free reconstitution of Fas-, UV radiation- and ceramide-induced apoptosis. EMBO J 14: $5191-5200$

Muzio M, Chinnaiyan A, Kischkel FC, O'Rourke K, Shevchenko A, Scaffidi C Bretz JD, Zhange M, Ni J, Reiner G, Mann M, Krammer PH, Peter ME and Dixit VM (1996) FLICE, a novel FADD homologous ICE/CED-3-like protease, is recruited to the CD95 (Fas/Apo-1) death-inducing signalling complex. Cell 85: 817-827

Nicholson DW, Ali A, Thornberry NA, Vaillancourt JP, Ding CK, Gallant M, Garaeau Y, Griffin PR, Labelle M, Lazebnik YA, Munday NA, Raju SM, Smulson ME, Yamin T-T, Yu VL and Miller DK (1995) Identification and inhibition of the ICE/CED-3 protease necessary for mammalian apoptosis. Nature 376: $37-43$

Niwa H, Yamamura K and Miyazaki J (1991) Efficient selection of highexpression transfectants with a novel eukaryotic vector. Gene 108: 193200.

Orth K, Chinnaiyan AM, Garg M, Froelich CJ and Dixit VM (1996a) The CED-3/ICElike protease Mch2 is activated during apoptosis and cleaves the death substrate lamin A. J. Biol. Chem. 271: 16443-16446

Orth K, O'Rourke K, Salvesen GS and Dixit VM (1996b) Molecular ordering of apoptotic mammalian CED-3/ICE-like proteases. J. Biol. Chem. 271: 2097720980

Sambrook J, Fritsch EF and Maniatis T (1989) Molecular Cloning: A laboratory manual. Second Edition. Cold Spring Harbor, New York: Cold Spring Harbor Laboratory Press

Song Q, Burrows S, Lees-Miller S, Smith G, Jackson S, Kumar S, Trapani JA, Alnemr E, Litwack G, Lu H, Moss D and Lavin MF (1996a) ICE-like protease cleaves DNA-dependent protein kinase in cytotoxic T-cell killing. J. Exp. Med. 184:619628

Song Q, Lees-Miller SP, Kumar S, Zhang N, Chan DW, Smith GCM, Jackson SP Alnemri ES, Litwack G, Khanna KK and Lavin MF (1996b) DNA-dependent protein kinase catalytic subunit: a target for an ICE-like protease in apoptosis. EMBO J. 15: $3238-3246$

Takahashi A, Alnemri ES, Lazebnik YA, Fernandes-Alnemri T, Litwack G, Moir RD, Goldman RD, Poirier GG, Kaufmann SH and Earnshaw WC (1996) Cleavage of lamin A by Mch2 $\alpha$ but not by CPP32: Multiple interleukin $1 \beta$-converting enzymerelated proteases with distinct substrate recognition properties are active in apoptosis. Proc. Natl. Acad. Sci. USA 93: 8395-8400
Tewari M, Quan LT, O'Rourke K, Desnoyers S, Zeng Z, Beidler DR, Poirier GG, Salvesen GS and Dixit VM (1995b) Yama/CPP32 $\beta$, a mammalian homologue of CED-3, is a CrmA-inhibitable protease that cleaves the death substrate poly(ADP-ribose) polymerase. Cell 81: 801-809

Thornberry NA, Bull HG, Calaycay JR, Chapman KT, Howard AD, Kostura MJ, Mille DK, Molineaux SM, Weidner JR, Aunins J, Elliston K O, Ayala, JM, Casano FJ, Chin J, Ding G J-F, Egger LA, Gaffney EP, Limjuco G, Palyha OC, Raju SM, Rolando AM, Salley JP, Yamin T-T, Lee, TD, Shively, JE, MacCross M, Mumford RA, Schmidt JA and Tocci MJ (1992) A novel heterodimeric cysteine protease is required for interleukin-1 $\beta$ processing in monocytes. Nature 356: 768-774

Van Criekinge W, Beyaert R, Van de Craen M, Vendenabeele P, Schotte P, De Valck $D$ and Fiers W (1996) Functional chracterization of the prodomain of interleukin$1 \beta$-converting enzyme. J. Biol. Chem. 271: 27245-27248

Wang L, Miura M, Bergeron L, Zhu H and Yuan J (1994) Ich-1, an Ice/ced-3-related gene, encodes both positive and negative regulators of programmed cell death. Cell 78: $739-750$

Walker NPC, Talanian RV, Brady KD, Dang LC, Bump NJ, Ferenz CR, Franklin S, Ghayur T, Hackett CR, Hammill LD, Herzog L, Hugunin M, Houy W, Mankovich JA, McGuiness L, Orlewicz E, Paskind M, Pratt CA, Reis P, Summani A, Terranova M, Welch JP, Xiong L, Möller A, Tracey DE, Kamen R and Wong WW (1994) Crystal structure of the cysteine protease interleukin-1 $\beta$ converting enzyme: a (p20/p10) 2 homodimer. Cell 78: 343-352

Waterhouse N, Kumar S, Song Q, Strike P, Sparrow, L, Dreyfuss G, Alnemri ES Litwack G, Lavin MF and Watters D (1996) Heteronuclear ribonucleoproteins C1 and $\mathrm{C} 2$, components of the spliceosome, are specific targets of interleukin $1 \beta$ converting enzyme-like proteases in apoptosis. J. Biol. Chem. 271: 2933529341

Wilson KP, Black J-A F, Thomson JA, Kim EE, Griffith JP, Navia MA, Murcko MA Chambers SP, Aldape RA, Raybuck SA and Livingston DJ (1994) Structure and mechanism of interleukin- $1 \beta$ converting enzyme. Nature $370: 270-275$

Xue D and Horvitz HR (1995) Inhibition of the Caenorhabditis elegans cell death protease CED-3 by a CED-3 cleavage site in baculovirus p35 protein. Nature 377: $248-251$

Xue D, Shaham S and Horvitz HR (1996) The Caenorhabditis elegans cell-death protein CED-3 is a cysteine protease with substrate specificities similar to those of the human CPP32 protease. Genes Develop. 10: 1073-1083

Yuan J, Shaham S, Ledoux S, Ellis H and Horvitz HR (1993) The C. elegans cell death gene ced-3 encodes a protein similar to mammalian interleukin- $1 \beta$-converting enzyme. Cell 75: 641-652 